\title{
Isolation and identification of Mycobacterium bovis in cattle slaughtered from an abattoir in Garanhuns, Pernambuco
}

\author{
Isolamento e identificação de Mycobacterium bovis em bovinos \\ abatidos em matadouro público de Garanhuns, Pernambunco
}

\author{
Stephanie Caroline Gueiros Silva ${ }^{1 *}$; Amanda de Deus Ferreira Alves \\ Tássio José de Oliveira Almeida ${ }^{3}$; Pamella Christhine Lins de Sát; \\ Antonio Franciso de Souza Filho ${ }^{5}$ Nicolás Céspedes Cárdenas ${ }^{6}$; \\ José Soares Ferreira Neto ${ }^{7}$; Marcos Bryan Heinemann ${ }^{8}$; \\ Sérgio Santos de Azevedo ${ }^{9}$; Márcia Bersane Araujo de Medeiros Torres ${ }^{10}$
}

\begin{abstract}
Tuberculosis is a chronic infectious disease caused by the Mycobacterium tuberculosis complex (CMT), members including $M$. bovis. The sanitary inspection in slaughterhouses has a great importance on public health for the removal of contaminated meat with pathological lesions. Cattle slaughtered in the abattoir of Garanhuns were subjected to macroscopic, histological, bacteriological, and molecular analyses. Lung inspection revealed gross lesions suggestive of tuberculosis. The characterization of tuberculous granulomas was performed by histopathology and hematoxylin and eosin(HE) staining. The identification of acid-fast bacilli (AFB) was performed on smears with fresh material and histological staining using Ziehl-Neelsen stain. Bacteriological diagnosis was carried out using Stonebrink and Lowenstein-Jensen media, and polymerase chain reaction (PCR) was performed from the DNA extracted from colonies for the identification of Mycobacterium spp. We found that $1 \%(32 / 3,180)$ of the collected lungs showed lesions suggestive of tuberculosis. Histopathological analysis revealed that $65.62 \%(21 / 32)$ samples had granulomatous pneumonia. AFB was detected in 46.88\% (15/32) smears and 4.16\% (1/24) histological sections, as analyzed by Ziehl-Neelsen staining. Moreover, $68.75 \%(22 / 32)$ samples showed bacterial growth and molecular identification $90 \%$ (18/20) of the samples were positive for $M$. bovis and $10 \%$ (2/20) for Mycobacterium sp. Thus, microbiological culture and PCR analyses revealed the high rate of bovine tuberculosis in this region, indicative of the need to disclose these results in the interest of public health. Consequently, we emphasize the need for an accurate macroscopic evaluation of lesions suggestive of bovine tuberculosis.
\end{abstract}

Key words: Granuloma. Pneumonia. Public health.

\footnotetext{
${ }^{1}$ Discente de Doutorado, Universidade Federal Rural de Pernambuco, UFRPE, Recife, PE, Brasil. E-mail: scaroline1@hotmail. com

2 Discente de Mestrado, UFRPE, Recife, PE, Brasil. E-mail: amanda_dedeus@hotmail.com

${ }^{3}$ Médico Veterinário Autônomo. E-mail: tassioalmeida@live.com

${ }^{4}$ Médica Veterinária Autônoma, Unidade Acadêmica de Garanhuns, UFRPE/UAG, Garanhuns, PE, Brasil. E-mail: sa.pamella@ hotmail.com

5 Discente de Doutorado, Universidade de São Paulo, USP, São Paulo, SP, Brasil. E-mail: antoniosouzafilho@gmail.com

${ }^{6}$ Discente de Mestrado, USP, São Paulo, SP, Brasil. E-mail: ncespedesc@unal.edu.com

7 Prof. Titular, USP, São Paulo, SP, Brasil. E-mail: jsoares@vps.fmvz.usp.br

${ }^{8}$ Prof. Dr., USP, São Paulo, SP, Brasil. E-mail: marcosbryan@usp.br

9 Prof. Associado, Universidade Federal da Paraíba, UFPB, Patos, PB, Brasil. E-mail: sergio@vps.fmvz.usp.br

${ }^{10}$ Prof. Adjunto IV, Unidade Acadêmica de Garanhuns, UFRPE/UAG, Garanhuns, PE, Brasil. E-mail: bersane@hotmail.com

* Author for correspondence
} 


\section{Resumo}

A tuberculose é uma doença infecciosa crônica causada por membros do complexo Mycobacterium tuberculosis (CMT), incluindo M. bovis. A inspeção sanitária em matadouros frigoríficos possui grande importância para a saúde pública pela remoção de carne contaminada com lesões patológicas. Os bovinos abatidos no matadouro de Garanhuns-PE foram submetidos a análises macroscópicas, histológicas, bacteriológicas e moleculares. A inspeção pulmonar revelou lesões sugestivas de tuberculose.A caracterização de granulomas tuberculoides foi realizada através da histopatologia e coloração de hematoxilina e eosina (HE). A identificação de bacilo álcool - ácido resistente (BAAR) foi realizado em esfregaços com material fresco e em cortes histológicos sob a coloração de Zihel-Neelsen. O diagnóstico bacteriológico foi realizado em meio de cultivo Stonebrink e Lowenstein-Jensen e a reação em cadeia da polimerase (PCR) sucedeu a partir de DNA extraído de colônias para identificação do Mycobacterium sp... Verificou-se que1\% (32/3.180) dos pulmões coletados apresentaram lesões sugestivas de tuberculose. Na análise histopatológica 65.62\% (21/32) amostras tinham pneumonia granulomatosa. BAAR foram detectados em 46,88\% (15/32) esfregaços e 4,16\% (1/24) em corte histológico conforme analisado pela coloração de Ziehl-Neelsen. Além disso, em 68,75\% (22/32) das amostras houve crescimento bacteriano e na identificação molecular $90 \%(18 / 20)$ das amostras foram positivas para M. bovis e 10\% (2/20 para Mycobacterium sp. Assim, a cultura microbiológica e as análises de PCR revelaram a alta taxa de tuberculose bovina na região, que indica a necessidade de divulgação desses resultados devido à importância da doença na saúde pública. Consequentemente, enfatizamos a necessidade de uma avaliação macroscópica precisa de lesões sugestivas de tuberculose bovina.

Palavras-chave: Granuloma. Pneumonia. Saúde pública.

\section{Introduction}

Tuberculosis is a chronic infectious disease caused by members of Mycobacterium tuberculosis complex (CMT), including M. tuberculosis, $M$. africanum, M. bovis, M. microti, M. caprae, $M$. pinnipedii, and M. cannettii (BROSCH et al., 2002). Although M. bovis is the most common agent of tuberculosis in cattle, other CMT species, including M. tuberculosis, M. caprae, and M. africanum have been detected (SAHRAOUI et al., 2009).

In cattle, tuberculosis presents chronic evolution and is characterized by granulomatous lesions located predominantly in the respiratory tract and associated tracheobronchial lymph nodes with mononuclear cell infiltrates such as macrophages, lymphocytes and multinucleated giant cells (NEILL et al., 1994).

The sanitary inspection of slaughterhouses is of great importance for public health for the removal of pathogen-contaminated meat as well as the meat with anatomopathological lesions suggestive of the disease (REIS, 2000).
Studies have shown that abscesses are important for the differential diagnosis (CAVAZANNI, 2009) and mainly are caused by bacteria such as Arcanobacterium pyogenes, Streptococcus spp., Pasteurella spp., Acinetobacter spp., and Pseudomonas spp. (FERNANDES et al., 2000). In addition, bronchopneumonia is also important and may be caused by bacterial agents including P. aeruginosa, Enterobacter spp., Proteus mirabilis, Staphylococcus epidermidis, Alcaligenes spp., Escherichia coli, and Klebsiella spp. (GONÇALVES, 2001).

Currently, the detection of mycobacteria in animal tissues is mainly based on conventional and complex methods involving Ziehl-Neelsen examination by smear, histopathology, and culture in selective media, followed by the biochemical or molecular identification of typical mycobacterial colonies.

Culturing is the gold standard method for confirming infection. Most molecular approaches are based on polymerase chain reaction (PCR) and specific target polymorphisms, insertion sequences, 
and so-called regions of difference in the genome of Mycobacterium spp. (REDDINGTON et al., 2012).

Affordable and rapid diagnostic methods such as Ziehl-Neelsen staining for the identification of acidfast bacilli (AFB) are of great importance for developing countries with high incidences of tuberculosis and financial constraints. However, there is an unmet need for more sensitive laboratory tests for the detection of infections in biological samples to provide greater efficacy in the control of tuberculosis (LAIFANGBAM et al., 2009).

Studies are necessary to identify tuberculous lesions in slaughterhouses and detect the most affected organs and the origin of animals. This may help in the greater control of the disease in the country while meeting the sanitary requirements of the international market for products related to animal origin aside from the importance of the control of this disease in the interest of public health (SILVA et al., 2014). Thus, the objective of the present work was to isolate and identify Mycobacterium spp. in samples of pulmonary lesions suggestive of tuberculosis in cattle slaughtered in Agreste of Pernambuco, Northeastern Brazil, followed by the macroscopic and microscopic evaluation of the lesions.

\section{Material and Methods}

The research was performed in public slaughterhouse of Garanhuns, Agreste of Pernambuco, during the period from January 2014 to July 2015. A total of 3,180 lungs of cattle were inspected and 32 pulmonary samples that presented macroscopic lesions suggestive of tuberculosis were collected according to the methods established by the Ministry of Agriculture and Manual of Standardization of Techniques, Facilities and Equipment for Inspection of Cattle Meat (BRASIL, 2013). In addition, animals were slaughtered from surrounding municipalities such as Brejão, Correntes, Lajedo, and Lagoa do Ouro.
The samples were divided into three parts and separated according to the diagnostic method to be used. One part was refrigerated for the evaluation by Ziehl-Neelsen staining by direct smear and for the identification of acid-fast bacilli (AFB) according to Souza et al. (2013). The second part of the sample was fixed in $10 \%$ formalin for histopathological analysis by hematoxylin and eosin (HE) staining and those suggestive of lesions were subjected to Ziehl-Neelsen Fite (EasyPath, São Paulo, Brazil) staining together with the positive control of bovine paratuberculosis to verify the presence of AFB. The lung fragments were embedded in paraffin and cut into sections ( $4 \mu \mathrm{m}$ thick) for the preparation of slides. The third part of the sample was frozen to perform a bacteriological culture and used for PCR analysis. For bacteriological culture, samples were decontaminated by the method of 1-hexadecylpyridinium chloride (HPC) (AMBRÓSIO et al., 2008) and incubated in duplicates in Stonebrink and Lowenstein-Jensen media at $37^{\circ} \mathrm{C}$ for 90 days. Colonies suggestive of mycobacteria were extracted for slide preparation for Ziehl-Neelsen staining and DNA extraction. DNA was extracted with thermolysis (MAZARS et al., 2001). Only samples positive for AFB in Ziehl-Neelsen staining were used for molecular identification.

The identification of mycobacteria and differentiation of CMT, M. avium complex, $M$. intracellulare complex, and Mycobacterium spp. were performed using TB Multiplex PCR. The primers used were as follows: MYCGEN-F (G1) (5'-AGAGTTTGATCCTGGCTCAG-3') and MYCGEN-R

( 5' T GCACA C A G GC C A C A A GGGA - 3') related to gender; $\mathrm{TB}-1 \mathrm{~F}$ (5'-GAACAATCCGGAGTTGACAA-3') and TB-1R (5'-AGCACGCTGTCAATCATGTA-3') related to $\mathrm{CMT}$; $\mathrm{MYCAV-R}$ (5'ACCAGAAGACATGCGTCTTG-3')

related to $M$. avium complex; and MYCINT-F (5'CCTTTAGGCGCATGTCTTTA-3') related to 
M. intracellulare complex (WILTON; COUSINS, 1992). H37Rv and AN5 strains were used as positive controls for M. tuberculosis and M. bovis, respectively. The reaction comprised $20 \mu \mathrm{L}$ ultrapure water, $2.5 \mu \mathrm{L}$ buffer, $1.25 \mathrm{M}$ DNTPs, $50 \mathrm{mM}$ magnesium chloride $\left(\mathrm{MgCl}_{2}\right), 10 \mathrm{pmol} \mu \mathrm{L}^{-1}$ of each primer, 1.25 U Taq DNA polymerase, and $2.5 \mu \mathrm{L}$ genomic DNA.

For the identification of M. bovis, allDNA samples withconsistentamplificationforCMTbyTBMultiplex PCR were amplified with the primers RD-4 (RD41, 5'-ATGTGCCTGGAGAGCGATG-3'; RD4-2, 5'-TGTACTATGCTGACCCATGCG-3'; and RD43, 5'-AAAGGAGCACCATCGTCCAC-3'). ). The same positive controls were used for M. tuberculosis and M. bovis. The strain H37Rv was donated by the Institute Adolf Lutz (IAL) and the strain AN5 was provided by Centro Panamericano de Zoonoses (CEPANZO). The amplified 268 bp products were identified as M. bovis, while those with 172 bp were identified as other CMT mycobacteria (WARREN et al., 2006). PCR that enabled such amplifications comprised $11.375 \mu \mathrm{L}$ ultra-pure water, $2.5 \mu \mathrm{L}$ buffer, $1.25 \mathrm{M}$ DNTPs, $50 \mathrm{mM} \mathrm{MgCl}_{2}, 10 \mathrm{pmol}$ $\mu \mathrm{L}^{-1}$ each primer, 1.25 U Taq DNA polymerase, and $2 \mu \mathrm{L}$ genomic DNA.

For the analysis of the association between variables, Fisher's exact test was used with the significance level of $5 \%$. The analysis was performed with IBM SPSS Statistics (Armonk, New York, USA) version 23.0 program.

\section{Results}

During the study period, $1 \%(32 / 3,180)$ of the samples presented macroscopic lesions suggestive of tuberculosis. In the macroscopic examination of the pulmonary lesions, higher areas were more noticeable around the borders of the caudal lobes. These nodules were firm, focal to multifocal, ranging from 0.5 to $2 \mathrm{~cm}$ in diameter. The nodulations mostly comprised an amorphous mass filled with yellowish-white cheesy material, which sometimes creaked at the cut owing to the process of calcification.

In two animals $(6.25 \%)$, these nodules were disseminated throughout the thoracic and abdominal cavity and the liver displayed several nodules on the capsular surface that were deepened by the parenchyma cut.

The evaluation of the histopathological examination of 32 samples revealed microscopic alterations, which helped in their classification as granulomatous pneumonia, pulmonary abscesses, suppurative bronchopneumonia, pulmonary emphysema, and interstitial pneumonia. The numbers and percentages of lung lesions observed in the histopathological examination are described in Table 1.

Table 1. Histopathological diagnosis, number of samples and percentage of pulmonary lesions suggestive of tuberculosis in cattle slaughtered at the public slaughterhouse of Garanhuns-PE, during the period from January 2014 to July 2015.

\begin{tabular}{lcc}
\hline \multicolumn{1}{c}{ Lesion } & Number of samples & \% of samples \\
\hline Granulomatous pneumonia & 24 & 75.00 \\
Abscesses & 4 & 9.37 \\
Suppurative bronchopneumonia & 2 & 6.25 \\
Emphysema & 1 & 3.13 \\
Interstitial Pneumonia & 1 & 3.13 \\
Total & $\mathbf{3 2}$ & $\mathbf{1 0 0}$ \\
\hline
\end{tabular}


Granulomatous pneumonia was microscopically characterized by multifocal granuloma, with areas of caseous necrosis and dystrophic calcification in the central region of the nodules. These areas were surrounded by an inflammatory reaction mainly comprising epithelioid macrophages, Langhanstype multinucleated giant cells, lymphocytes, some plasma cells, and rarely neutrophils.

Ziehl-Neelsen staining of the tissue smear revealed that $46.88 \% \quad(15 / 32)$ samples were positive for AFB. These were detected mostly in macrophages and necrotic areas in $4.16 \%(1 / 24)$ samples of granulomatous pneumonia, as analyzed by Ziehl-Neelsen Fite method.
Bacteriology analysis showed bacterial isolation from $68.75 \% \quad(22 / 32)$ samples. In molecular diagnosis, a total of $91 \%(20 / 22)$ samples were amplified from the microbiological culture; of these, 90\% (18/20) samples were positive for $M$. bovis and 10\% (2/20), for Mycobacterium spp. However, 9.10\% (2/22) samples positive in culture were negative in PCR analysis.

We observed an association between the occurrence of histopathological lesions and results of culture $(\mathrm{P}=0.001)$, $\mathrm{PCR}(\mathrm{P}=0.005)$, and Ziehl-Neelsen by smear $(\mathrm{P}<0.001)$; however, no association was observed between the occurrence of histopathological lesions and Ziehl-Neelsen Fite results $(\mathrm{P}=0.656)$, as shown in Table 2 .

Table 2. Presence of lesions in the histopathological survey against positivity in the diagnostic tests for tuberculosis in cattle slaughtered at the public slaughterhouse of Garanhuns-PE during the period from January 2014 to July 2015.

\begin{tabular}{llcc}
\hline \multicolumn{1}{c}{ Diagnostic test $^{\mathbf{a}}$} & $\mathbf{N}^{\mathbf{0}}$ & Presence of lesions in Histopathology & Value $^{\mathbf{b}}$ \\
\hline Culture & 32 & $19(59.30 \%)$ & $0.001^{*}$ \\
PCR & 32 & $17(53.10 \%)$ & $0.005^{*}$ \\
Ziehl-Neelsen smear & 32 & $15(46.80 \%)$ & $<0.001^{*}$ \\
Ziehl-Neelsen FITE & 32 & $1(3.10 \%)$ & 0.656 \\
\hline
\end{tabular}

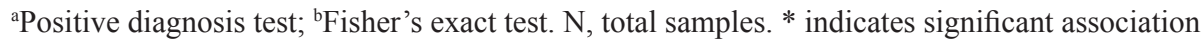
$(\mathrm{P}<0,05)$.

\section{Discussion}

Jorge (2010) reported that most lesions occurred in the thoracic region, consistent with the observation in the present study. In cattle, most lesions are found in the lower respiratory tract, and upper and regional lymph nodes. In this species, the inhalation of contaminated droplets through cough or nasal secretion of an animal with active pulmonary tuberculosis is most likely to cause infection (NEILL et al., 1994). Concerning the distribution of lesions, the findings in this study are in line with those reported by Costa et al. (2013) who observed focal, multifocal, or diffuse nodular lesions.

It may take weeks or months for the granuloma to be macroscopically visible; these small foci are tubers and constitute the initial macroscopic changes (McGAVIN; ZACHARY, 2009). With the progression of the disease, these tubers form large areas of caseous necrosis, and posterior calcification of granuloma is typical (FRANÇA et al., 2013). Silva et al. (2014) evaluated 100 carcasses with morphological lesions suggestive of tuberculosis and found that $85 \%$ and $15 \%$ were classified as caseous and calcified, respectively, corroborating the results of the present study that demonstrates macroscopy of lesions with a caseous aspect sometimes with gritty cut surface.

Granulomatous pneumonia is characterized by the accumulation of inflammatory cells, with the predominance of macrophages, epithelioid macrophages, multinucleated giant cells, and 
lymphocytes, in addition to central necrosis with mineralization (CASSIDY, 2006). In the present study, these characteristics were observed to be similar to those described in bovines experimentally inoculated with $M$. bovis (POLLOCK et al., 2006) and naturally infected cattle (MEDEIROS et al., 2012).

Some neutrophils were also visualized in one sample, in agreement with the findings of Charro e Osório (2009). Neutrophils may be present in the initial phase of granulomas and are usually replaced by macrophages; these cells may be found to degenerate in isolated forms or groups close to the necrotic region (CASSIDY et al., 1999).

Among the differential diagnoses cited in the literature, abscesses (CAVAZANNI, 2009) and bronchopneumonia (GONÇALVES, 2001) were observed. These lesions generally have bacterial etiology; however, no microbiological examinations were performed in this study. Emphysema and interstitial pneumonia are lesions not considered as common differential diagnoses for tuberculosis during the inspection of lungs. Pulmonary emphysema may be attributed mainly to the inadequate management of animals during desensitization, compromising the efficiency of practice, and bleeding or can be secondary to interstitial pneumonia, and its disposal is indicated by the Brazilian regulation, named Regulamento de Inspeção Industrial e Sanitária de Produtos de Origem Animal (RIISPOA) (BAPTISTA, 2008).

The identification of AFB in the smear showed a high value in Ziehl-Neelsen staining as compared with the variation in the frequency of Ziehl-Neelsen staining in different studies, $17.90 \%$ by Varello et al. (2008) and 36.80\% Laisse et al. (2011). Similar findings about AFB location in the giant cells or necrosis area using histological sections were described in cattle (FRANÇA et al., 2013) and goats (SEVA et al., 2002). The scarce number of bacteria in the lesion in histological sections or direct smears may determine the absence of these bacilli, a characteristic observed by Andrade et al. (1991), wherein only one lesion with bacilli was identified in the histological section. The low number or absence of bacteria in the lesion occurs through the progression of late hypersensitivity reaction during the development of central caseous necrosis, and peripheral fibrosis, which evolves into resolution and calcification. The intact bacterial membranes retain the dyeing characteristics, while the rupture of the membrane results in the loss of the characteristics of acid-fast bacilli. (PALMER et al., 2012).

We observed higher values for AFB isolation rate as compared to previous studies, which showed $23.60 \%$ (17/72) (ARAÚJO et al., 2005) and 48.10\% (89/185) (PARREIRAS et al., 2012). The culture used in these studies was the most sensitive test. However, the results obtained in this study were similar to those observed in the study in a dairy herd of Tatuí, Brazil, which showed 60\% (18/30) of the positive samples in the culture (NASSAR et al., 2007).

Two samples were negative by PCR analysis even with suggestive colonies in the culture were identified. In addition to the possible inhibitors of PCR or possible defects in the performance of the reaction (MICHEL et al., 2010), factors such as DNA concentration in the reaction and genetic variability may justify these findings.

The association data found in Fisher's test corroborate with the findings of Fráguas et al. (2008), where a significant association was observed between smear microscopy and histopathology. On the other hand, this association contradicted the results of Silva (2015).

The association of histopathological lesions and PCR demonstrate values different than those observed in the study by Proaño-Pérez et al. (2011), where a weak association was identified. However, no association was observed with Ziehl-Neelsen Fite. The absence of AFB in the histological sections may be frequent in bovine tuberculosis, 
owing to the low number of bacteria within the lesion (ANDRADE et al., 1991).

The Ministry of Agriculture intends to eradicate bovine tuberculosis and there is a lag in the official rate of tuberculosis prevalence in this species, highlighting the need for new official data. In addition, the standard gold diagnosis is timeconsuming and the disease spreads more rapidly among HIV-infected individuals (CORRÊA, 2011). Thus, the combination of laboratory analysis and inspection is useful to increase the detection of Mycobacterium and may be used as a surveillance and control tool for this zoonosis (SOUZA et al., 2013).

\section{Conclusion}

Microbiological culture and PCR provided a confirmatory diagnosis of a high rate of bovine tuberculosis in the region, and it is necessary to disseminate the results to raise awareness of the disease.

Given the variability of the lesions suggestive of tuberculosis at different stages during differential diagnoses, we emphasize the importance of a thorough macroscopic evaluation. There is a restriction for the veterinarian to perform only macroscopic examination of the organ from the slaughterhouse to avoid economic losses caused by wrongful conviction of the carcass.

\section{Acknowledgments}

We thank the National Council for Scientific and Technological Development (CNPq) for funding the scholarship during the execution of the project and the Veterinary Pathology Laboratory of UFCG - Campus Patos-PB.

\section{References}

AMBRÓSIO, S. R.; OLIVEIRA, E. M. D.; RODRIGUEZ, C. A. R.; FERREIRA NETO, J. R.; AMAKU, M. Comparison of three decontamination methods for Mycobacterium bovis isolation. Brazilian Journal of Microbiology, São Paulo, v. 2, n. 39, p. 241-244, 2008.

ANDRADE, G. B.; RIET-CORREA, F.; MIELKE, P. V.; MÉNDEZ, M. D. C.; SCHILD, A. L. Estudo histológico e isolamento de micobactérias de lesões similares à tuberculose em bovinos no Rio Grande do Sul. Pesquisa Veterinária Brasileira, Rio de Janeiro, v. 11, n. 3-4, p. 81-86, 1991.

ARAÚJO, C. P.; LEITE, C. Q. F.; PRINCE, K. A.; JORGE, K. S. G.; OSÓRIO, A. L. A. R. Mycobacterium bovis identification by a molecular method from postmortem inspected cattle obtained in abattoirs of Mato Grosso do Sul, Brazil. Memórias do Instituto Oswaldo Cruz, Rio de Janeiro, v. 7, n. 100, p. 749-752, 2005.

BAPTISTA, A.T. Quantificações das condenações em vísceras de bovinos em 2007 nos matadouros-frigorificos do estado do Espírito Santo registrados no serviço de inspeção estadual. 2008. Monografia (Graduação em Medicina Veterinária) - Universidade Castelo Branco, Vitória.

BRASIL. Ministério da Agricultura, Pecuária e Abastecimento. Regulamento da Inspeção Industrial e Sanitária de Produtos de Origem Animal - RIISPOA. Brasília, 2013. 241 p. Disponível em: <http: <//www.agricultura.gov.br/ arq_editor/file/Aniamal/MercadoInterno/Requisitos/ RegulamentoInspecaoIndustrial.pdf $>$. Acesso em: 24 jun. 2015.

BROSCH, R.; GORDON, S. V.; MARMIESSE, M.; BRODIN, P.; BUCHRIESER, C.; EIGLMEIER, K.; GARNIER, T.; GUTIERREZ, C.; HEWINSON, G.; KREMER, K.; PARSONS, L. M.; PYM, A. S.; SAMPER, S.; VAN SOLLIGEN, D.; COLE, A. A new evolutionary scenario for the Mycobacterium tuberculosis complex. Proccedings of National Academy of Sciences of the United States of America, Brighton, v. 99, n. 6, p. 36843689, 2002.

CASSIDY, J. P. The pathogenesis and pathology of bovine tuberculosis with insights from studies of tuberculosis in humans and laboratory animal models. Veterinary Microbiology, Geneva, v. 112, n. 2-4, p. 151-161, 2006.

CASSIDY, J. P.; BRYSON, D. G.; POLLOCK, J. M.; EVANS, R. T.; FORSTER, F.; NEILL, S. D. Lesions in Cattle Exposed to Mycobacterium bovis-inoculated Calves. Journal of Comparative Pathology, Stormont, v. 121, n. 4, p. 321-337, 1999. 
CAVAZANNI, L. F. M. Diagnóstico imunológico, histopatológico e molecular das subspecies do Complexo Mycobacterium tuberculosis em amostras de bovinos da região centro-oriental do Paraná, Brasil. 2009. Dissertação (Mestrado em Biologia Celular e Molecular) - Universidade Federal do Paraná, Curitiba.

CHARRO, F. D.; OSÓRIO, A. L. A. R. Diagnóstico da tuberculose bovina por meio de histopatologia. Campo Grande: [S.1.], 2009. Disponível em: <http://www.propp. ufms.br/gestor/titan.php?target $=$ open File\&fileId $=429>$. Acesso em: 05 dez. 2015.

CORRÊA, F. A. F. Formas de diagnóstico de Mycobacterium tuberculosis e Mycobacterium bovis. 2011. (Disciplina de Mestrado em Ciência Animal) Universidade Federal de Goiás, Goiânia.

COSTA, P.; FERREIRA, A. S.; AMARO, A.; ALBUQUERQUE, T.; BOTELHO, A.; COUTO, I.; CUNHA, M.V.; VIVEIROS, M. Enhanced detection of tuberculous mycobacteria in animal tissues using a seminested probe-based real- time PCR. Plos One, Lisboa, v. 11, n. 8, p. 81-337, 2013.

FERNANDES, C. G.; SCHILD, A. L.; RIET-CORREA, F.; BAIALARDI, C. E. G.; STIGGER, A. L. Pituitary abscess in young calves associated with the use of a controlled suckling device. Journal of Veterinary Diagnostic Investigation, Visalia, v. 12, n. 1, p. 70-71, 2000.

FRÁGUAS, S. A; CUNHA-ABREU, M. S.; FERREIRA A. M. R.; MARASSI, C. D.; OELEMANN, W.; FONSECA, L. S.; FERREIRA, R.; LILENBAUM, W. Estudo comparativo de métodos complementares para o diagnóstico da tuberculose bovina em animais reagentes à tuberculinização. Revista Brasileira de Ciência Veterinária, Rio de Janeiro, v. 3, n. 15, p. 117-121, 2008.

FRANÇA, L. R.; CRUZ, J. F.; NEVES, V. B.; CERQUEIRA, R. B. Prevalência e histopatologia de lesões sugestivas de tuberculose em carcaça de bovinos abatidos no Sudoeste da Bahia. Revista Brasileira de Saúde Produção Animal, Salvador, v. 4, n. 14, p. 721733, 2013.

GONÇALVES R. C.; KUCHEMBUCK, M. R. G.; CURI, P. R.; CHIACCHIO, S. B.; ALMEIDA, C. T.; BORGES, A. S. Diferenciação clínica da broncopneumonia moderada e grave em bezerros. Ciência Rural, Santa Maria, v. 31, n. 2, p. 263-269, 2001.

JORGE, K. S. G. Identificação de mycobacterium bovis em bovinos e sua importância na ocorrência de tuberculose zoonótica. 2010. Tese (Doutorado em Saúde e Desenvolvimento na Região Centro-Oeste ) Universidade Federal de Mato Grosso do Sul, Campo Grande.
LAIFANGBAM, S.; SINGH, H. L.; SINGH, N. B.; DEVI, K. M.; SINGH, N. T. A comparative study of fluorescent microscopy with Ziehl-Neelsen staining and culture for the diagnosis of pulmonary tuberculosis. Kathmandu University Medical Journal, Kathmandu, v. 3, n. 7, p. 226-230, 2009.

LAISSE, C. J. M.; GAVIER-WIDÉN, D.; RAMIS, G.; BILA, C. G.; MACHADO, A.; QUEREDA, J. J.; AGREN, E. O.; HELDEN, P. D. Characterization of tuberculous lesions in naturally infected African buffalo (Synceruscaffer). Journal of Veterinary Diagnostic Investigation, Visalia, v. 23, n. 5, p. 1022-1027, 2011.

MAZARS, E.; LESJEAN, S.; BANULS, A.; GILBERT, M.; VICENT, V.; GICQUEL, B.; TIBAYREBNC, M.; LOCHT, C.; SUPPLY, P. High-resolution minisatellitebased typing as a portable approach to global analysis of Mycobacterium tuberculosis molecular epidemiology. Proceedings of the National Academy of Sciences, USA, v. 98, n. 4, p.1901-1906, 2001.

MCGAVIN, M. D.; ZACHARY, J. F. Pathologic basis of veterinary disease. $5^{\text {th }}$ ed. Elsevier: St Louis, 2009. 1476 p.

MEDEIROS, L. S.; MARASSI, C. D.; FIGUEIREDO, E. E. S.; LEITE, J.; FERREIRA, A. M. R.; LILENBAUM, W. Assessing the histopathology to depict the different stages of bovine tuberculosis infection in a naturally infected herd. Pesquisa Veterinária Brasileira, Rio de Janeiro, v. 2, n. 32, p. 135-139, 2012.

MICHEL, A. L.; MULLER, B.; VAN HELDEN, P. D. Mycobacterium bovis at the animal-human interface: a problem, or not? Veterinary Microbiology, Geneva, v. 140, n. 3-4, p. 371-378, 2010.

NASSAR, A. F.; MIYASHIRO, S.; OLIVEIRA, C. G.; PACHECO, W. A.; OGATA, R. A. Isolation and identification of bovine tuberculosis in a Brazilian herd (Sao Paulo). Memórias do Instituto Oswaldo Cruz, Rio de Janeiro, v. 5, n. 102, p. 639-42, 2007.

NEILL, S. D.; POLLOCK, J. M.; BRYSON, D. B.; HANNA, J. Pathogenesis of Mycobacterium bovis infection in cattle. Veterinary Microbiology, Geneva, v. 40, n. 1-2, p. 41-52, 1994.

PALMER, M. V.; THACKER, T. C; RAYWATERS, R; GORTAZAR, C.; CORNER, L. A. L. Mycobacterium bovis: a model pathogen at the interface of livestock, wildlife, and humans. Veterinary Medicine International, Cairo, v. 2, n. 1, p. 236-205, 2012.

PARREIRAS, P. M.; ANDRADE, G. I.; NASCIMENTO, T. F.; OELEMANN, M. C.; GOME, H. M.; ALENCAR, A. P.; ASSIS, R. A.; MOTA, P. M. P. C.; PEREIRA, M. A. S.; LOBATO, F. C. F.; LAGE, A. P.; SUFFYS, P. 
N. Spoligotyping and variable number tandem repeat analysis of Mycobacterium bovis isolates from cattle in Brazil. Memórias Instituto Oswaldo Cruz, v. 107, n. 1, p. 64-73, 2012.

POLLOCK, J. D.; RODGERS, J. D.; WELSH, M. D.; MCNAIR, J. Pathogenesis of bovine tuberculosis: the role of experimental models of infection. Veterinary Microbiology, Geneva, v. 112, p. 141-150, 2006.

PROAÑO-PEREZ, F.; BENÍTEZ-ORTIZ, W.; DESMECHTD, D.; MARCO, C.; ORTIZ, J.; RON, L.; PORTAELS, F.; RIGOUTS, L.; LINDEN, A. Postmortem examination and laboratory-based analysis for the diagnosis of bovine tuberculosis among dairy cattle in Ecuador. Preventive Veterinary Medicine, Colorado, v. 101, n. 1-2, p. 65-72, 2011.

REDDINGTON, K.; ZUMLA, A; BATES, M.; SOOLINGEN,' D.; NIEMANN, D.; BARRY, T.; O'GRADY, J. Seek TB, a two-stage multiplex real-timepcr-based method for differentiation of the mycobacterium tuberculosis Complex. Journal of Clinical Microbiology, Washigton DC, v. 2, n. 50, p. 203-2206, 2012.

REIS, D. O. Importância do exame histopatológico para o diagnóstico pós-mortem de bovinos abatidos em frigorífico de Uberlândia-MG. Higiene Alimentar, Mirandópolis, v. 78-79, n. 11, p. 23-27, 2000.

SAHRAOUI, N.; MÜLLER，B.; GUETARNI，D.; BOULAHBAL, F.; YALA, D.; OUZROUT, R.; BERG, S.; SMITH, N.H.; ZINSSTAG, J. Molecular characterization of Mycobacterium bovis strains isolated from cattle slaughtered at two abattoirs in Algeria. Veterinary Research, Blida, v. 4, n. 5, p. 1-7, 2009.

SEVA, J.; MENCHÉN, V.; NAVARRO, J.A.; PALLARES, F. J.; VILLAR, D.; VASQUEZ, F.; BARNABE, A. Caprine tuberculosis eradication program: an immunohistochemical study. Small Ruminant Research, Arkansas, v. 46, n. 2-3, p. 107-114, 2002.
SILVA, D. A. V. Comparação entre métodos diagnósticos da tuberculose em bovinos abatidos nos matadourosfrigorificos do Estado de São Paulo. 2015. Dissertação (de Mestrado em Medicina Veterinária) - Faculdade de Ciências Agrárias e Veterinária. Universidade Estadual Paulista, São Paulo.

SILVA, D. A. V.; BÜRGER, K. P.; MARTINS, A. M. C. V.; PROVIDELLO, A. Identificação de lesões macroscópicas sugestivas de tuberculose bovina. Revista Brasileira de Higiene e Sanidade Animal, Fortaleza, v. 2, n. 8, p. 149-160, 2014.

SOUZA, R. F. P.; LUVIZOTTO, M. C. R.; FERNANDES, J. O. M.; FERRARI, H. M. Caracterização histomorfológica de lesões granulomatosas sugestivas de tuberculose ganglionar e pulmonar em bovinos abatidos na Região Noroeste do Estado de São Paulo. Ciências Agrárias e Saúde, Andradina, v. 9, n. 1, p. 27-35, 2013.

VARELLO, K.; PEZZOLATO, M.; MASCARINO, D.; INGRAVALLE, F.; CARAMELLI, M.; BOZZETTA E. Comparison of histologic techniques for the diagnosis of bovine tuberculosis in the framework of eradication programs. Journal of Veterinary Diagnostic Investigation, Visalia, v. 20, n. 2, p. 164-169, 2008.

WARREN, R. M.; GEY VAN PITTIUS, N. C.; BARNARD, M.; HESSELIN, A.; ENGELKE, E.; KOCK, M. de; GUTIERREZ, M. C.; CHEG, G. K.; VICTOR, T. C.; HOAL E. G.; VAN HELDEN, P. D. Differentiation of Mycobacterium tuberculosis complex by PCR amplification of genomic regions of difference. International Journal of Tuberculosis and Lung Disease, Washington DC, v. 7, n. 10, p. 818-822, 2006.

WILTON, S.; COUSINS, D. detection and identification of multiple mycobacterial pathogens by dna amplification in a single tube. Genome Research, Washington DC, v. 1, n. 4, p. 269-273, 1992. 
